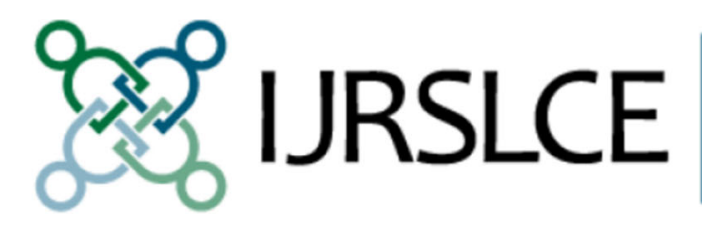

International Journal

for Research on

Service-Learning \&

Community Engagement

\title{
Faculty Roles and Faculty-Related Topics
}

\section{Lina D. Dostilio}

This article was originally published at:

https://journals.sfu.ca/iarslce/index.php/journal/article/view/161/85

Recommended Citation

Dostilio, L. D. (2015). Faculty roles and faculty-related topics. International Journal of Research on Service-Learning and Community Engagement, 3(1), Article 9. 


\title{
Faculty Roles and Faculty-Related Topics
}

\author{
Lina D. Dostilio \\ Dusquene University
}

\section{Section Editor}

Faculty who practice service-learning and community engagement are engaged scholars who focus their teaching and research on the renewal of democracy and social and environmental issues of relevance to the broader public. Their scholarship comprises a vehicle for their personal commitments and, in some cases, their respective institution's commitments to the civic purposes of higher education. Faculty who effectively use service-learning and community-engaged pedagogies prioritize active, experiential methods, including student inquiry and community action. They embrace broader epistemologies that honor a diversity of perspectives including different ways of knowing and community-based knowledge. The research practices of faculty in service-learning and community engagement are typically more collaborative and action-oriented than is traditional in academic disciplines; the aim of research is the enhancement of the polity or public life achieved through continuous cycles of inquiry and action. Despite support for community-engaged work in the scholarship on higher education (Boyer, 1990), faculty who practice these approaches often face institutional barriers to tenure, promotion, and other rewards.

Two articles in this issue of IJRSLCE focus on faculty-related inquiry, with both exploring the meaning that community engagement brings to a faculty member's career. In "Mid-Career Faculty and High Levels of Community Engagement: Intentional Reshaping of Meaningful Careers," DeFelippo and Giles investigate the career fulfillment for mid-career faculty who pursue community engagement focused on social problems and change. In the second article, "Is Service-Learning Worth It?: A Mixed-Methods Study of Faculty's Service-Learning Experiences," Blakey, Theriot, Cazzell, and Sattler discuss the impact of service-learning teaching on faculty. Their study yielded insight into faculty transformation, emotional investment, as well as concerns held by faculty about their experiences. Both studies utilized a mixed-methods design, leveraging quantitative survey data along with interview data (DeFelippo and Giles) and case study data (Blakey et al.) to draw conclusions. Together they represent an important line of inquiry - the ways adopting service-learning and community engagement affect faculty — and both suggest that a sense of fulfillment can be gained from this work, albeit while also contributing some discomfort or concern. 